\title{
トンネル機械の水平位置計測法
}

\section{METHOD TO MEASURE HORIZONTAL POSITION OF TUNNELLING MACHINE}

\author{
野村由司彦*・保科宏**・梅 津 孝 雄*** \\ By Yoshihiko NOMURA, Hiroshi HOSHINA and Takao UMEZU
}

\begin{abstract}
In the field of small-diameter tunnelling, one of the biggest factors standing in the way of the realization of constructing long span and curved tunnels has been the difficulty of measuring the horizontal position of a tunnelling machine. This paper describes a mesurement method which emits a magnetic field from a coil in the tunnelling machine and detects the source of the transmission by the use of two search coils. A 90-meter long tunnel with a 200-meter radius of curvature was constructed, and it was confirmed that the horizontal position found by this method is accurate to a certain specified centimeter. These results indicate the utility of this simple and precise horizontal position measurement method for tunnel construction work.
\end{abstract}

\section{1. まえがき}

近年, 電気通信ケーブル，上下水道，ガス，電力なよ゙ の管埋設工事において，騒音，振動等の低減への住民の 要望, 埋設物のふくそうによる大深度化, 施工時の安全 性の確保なよ゙のため, 開削工法に代わり, トンネル工法 が広く用いられるようになってきている。このトンネル 工法において, 道路の線形に合わせる, 障害物を避ける, 経済性を向上させるなよ゙の理由から，長距離かつ曲線に 管を埋設する技術の需要が高まっている．この技術の実 現には,トンネル機械が推進方向を修正できるとともに， 曲線状に推進するトンネル機械の位置を正確に計測でき ることが条件である.

また，電気通信ケーブルの分野では，広帯域特性，細 径性などの特徴を有する光ケーブル伝送方式の実用化に より，800 mm 以下の小口径管はますます重要になって いる. しかしながら, 従来, 小口径管の場合, 人間がト ンネル内に入って光学測量できないので, 発進地点から, レーザやトランシットによってトンネル機械を直接見通

* 正会員 工修 日本電信電話株式会社 NTT 茨城電気通 信研究所通信土木研究室 研究主任

** 正会員 同研究室 研究専門調查員

*** 東京総支社施設部土木課

（３19-11 茨城県東海村白方白根 162）
して位置を計測していた。そのため，小口径のトンネル 工法は, $30 \mathrm{~m} \sim 50 \mathrm{~m}$ の短距離・直線施工に限られてい だ!

トンネル機械の位置には, 推進距離, 計画線からの水 平位置, そして深さの 3 要素があるが, 推進距離は埋設 管の押込量から容易に計測できる。また，深さは重力を 利用した傾斜角検出器等からも推定することができるの で, 計測上の問題となっているのは水平位置である.

従来, 地中の物体の絶対位置を計測する技術としては, 弾性波法, 電磁波法, 磁界による方法などがあった。し かし，これらの方法は，いずれも小口径トンネル機械の 水平位置計測に要求される条件, 適用深さ $5 \mathrm{~m}$, 精度数 $\mathrm{cm}$ に及ばず，適用できない。すなわち，弾性波法 ${ }^{21}$ は 地中での損失が大きく適用深さが $1.5 \mathrm{~m}$ 程度であり, 電磁波法 ${ }^{3)}$ は, 深さ $5 \mathrm{~m}$ 程度まで適用できるものの, 分 解能が深さ $3 \mathrm{~m}$ で $50 \mathrm{~cm}$ であり, 磁界によってケーブ ルの水平位置を計測する方法 ${ }^{4}$ は適用深さが $3 \mathrm{~m}$, 精度 が深さの $10 \%$ である.

そこで, 著者らは, 先に, 磁界を用いて一定距離ごと に計測される絶対水平位置 ${ }^{5}$ により, 推定方位角から計 算で求められる水平位置を較正する方法を提案した ${ }^{61}$.

しかしながら,この磁界による水平位置計測法は,サー チコイルの鉛直度を調整した後，走査するものであり， 
計測に時間と熟練を必要としていた。そこで，本論文は 誘起電圧の空間分布を究明し，その特性を忍用すること によって，サーチコイルの調整や走査を不要にする新し い計測法を提案するとともに，小门径のトンネル機械に 適用し，長距離・曲線トンネル施工実験によりその実用 性を明らかにしている。

\section{2. 計 測 方法}

\section{（1）磁界による計測法の基礎}

a) 構成 本位置計測法の構成を Fig. 1 に六す. 軸心が鉛直となるようにトンネル機械内に設けられたコ イルへ発進坑内の発振器から, 交流電流を紷電する。 してコイルから発せられた交流磁界によって地上のサー チコイルに誘起された電圧を選択レベル計により計測す るシステムである.

b ）誘起電圧の空間分布 トンネル機械内のコイ ル (コイル半径： $a$, コイル長 : $l$, 巻数 $\left.N_{1}\right)$ に電流 $I$ $\left(\sqrt{2} I_{i} \sin 2 \pi f t\right)$ が流れることによって発生する磁界 $\vec{H}$ の $x, y, z$ 成分 $\left(H_{x}, H_{y}, H_{z}\right)$ 之, 水平位置 $(x, y)$ および 深さ $z$ の間には, $a \ll \sqrt{x^{2}+y^{2}+z^{2}}, \quad l \ll \sqrt{x^{2}+y^{2}+z^{2}}$ のとき,

$$
\begin{aligned}
& H_{x}=\frac{3 N_{1} I a^{2}(x / z)}{4 z^{3}\left\{1+\left(x^{2}+y^{2}\right) / z^{2}\right\}^{5 / 2}} \\
& H_{y}=\frac{3 N_{1} I a^{2}(y / z)}{4 z^{3}\left\{1+\left(x^{2}+y^{2}\right) / z^{2}\right\}^{5 / 2}} \\
& H_{z}=\frac{N_{1} I a^{2}\left\{2-\left(x^{2}+y^{2}\right) / z^{2}\right\}}{4 z^{3}\left\{1+\left(x^{2}+y^{2}\right) / z^{2}\right\}^{5 / 2}}
\end{aligned}
$$

が成り立つ").

この磁界によって巻数 $N_{2}$ のサーチコイルに誘起され る電圧 $V(t)$ は,
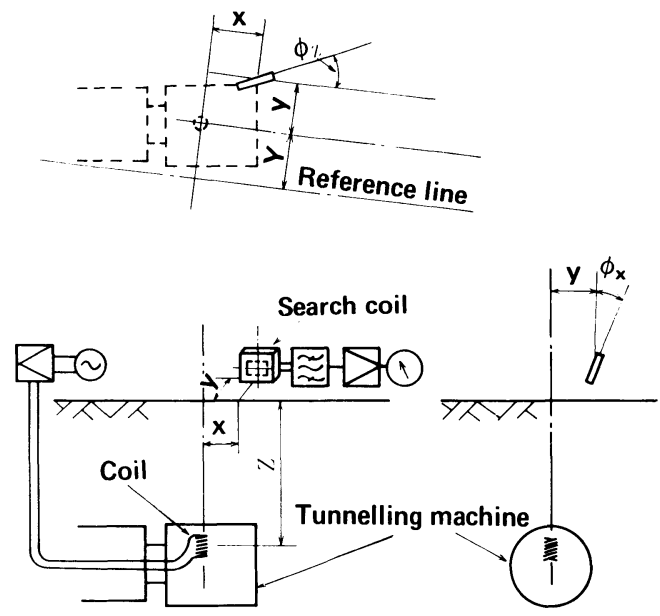

Fig. 1 Fundamental constitution of horizontal position measurement.

$$
V(t)=-N_{2} \mu(\vec{S} \cdot d \vec{H} / d t)
$$

となる.ただし， $\mu$ ：コイル間の媒質の誘磁率， $\vec{S}:$ サ一 チコイルの鎖交面の面積 $S$ の大ききをもち，鎖交面の 法線方向を向くベクトル $\left(S \cos \phi_{x} \sin \phi_{z}, S \cos \phi_{x}\right.$ $\left.\cos \phi_{z}, S \sin \phi_{x}\right)$

\section{(2) 計測原理}

a ）従来法 サーチコイルの鎖交面を鉛直，かつ トンネルを築造しようとする計画線（ $x$ 軸）に平行に保 持し, 計画線に直角な方向（ $y$ 軸）にサーチコイルを移 動する場合について考える.このとき，Fig.1において， $\phi_{x}=0, \phi_{z}=0$ であり，かつ推進距離は他の方法により

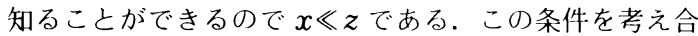
わせ，式（1)（３）を式（4）に代入すれば，誘起電 圧 $V$ (実効値) として

$$
V=\alpha y / z^{4} /\left(1+y^{2} / z^{2}\right)^{5 / 2}
$$

を得る.ただし， $\alpha$ は $3 \pi f \mu N_{1} N_{2} a^{2} S I_{i} / 2$ であり，一定 值となる。また， $z$ も一定であることから， $V$ の最小 値を示すサーチコイルの位置 $(y=0)$ を，走查により 求めれば，サーチコイル，すなわちトンネル機械の水平 位置が得られる。この方法が著者らがこれまで用いてき たものであり

式（5）の関係を空中での実験により確認した。ここ で，周波数 $f$ は近傍金属体による影響が小さい $220 \mathrm{~Hz}$ とじ，人力電圧 $V_{i}$ は $30 \mathrm{~V}$ ないし $45 \mathrm{~V}$ とした．Fig. 2 に示すように, $y / z=0.1$ における誘起電压 $V_{y / z=0.1}$ と, 任意の $y / z$ における $V$ との比の理論值 $(y / z) / 0.1$ / $\left(1+y^{2} / z^{2}\right)^{2.5}$ と実験値は, 深さ $z=1.1,2.0,2.8 \mathrm{~m}$ の条 件でほぼ一致した。この結果, $V_{\propto} y /\left(1+y^{2} / z^{2}\right)^{2.5}$ の関係 が広範囲の $y / z$ に対して成立する。ささらに, $y / z$ が小 さいときは, 式 $(5)$ の $\left(1+y^{2} / z^{2}\right)^{2.5}$ を 1 として, 近似 式

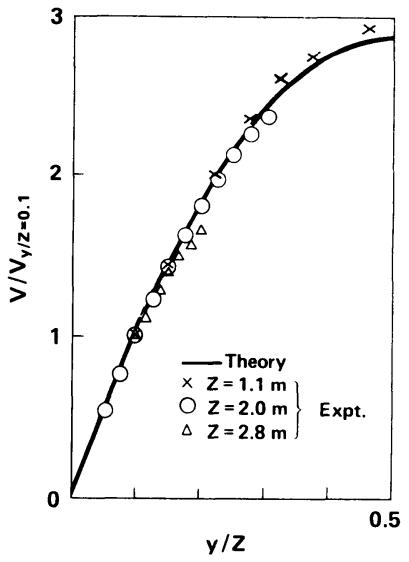

Fig. 2 Relations between induced voltage ratio and ratio of horizontal to vertical position of search coil. 


$$
V=\alpha y / z^{4}
$$

を得る.ここで，同じ実験を $z=5 \mathrm{~m}$ まで行ったところ，

Fig. 3 に示すように, $5 \leq y \leq 60 \mathrm{~cm}$ での $V$ と $y$ との比 例関係は，深くなるにつれ広範囲で成立していることが わかる。

また, Fig. 3 の結果から水平変位 $y$ が等しいときの誘 起電圧 $V$ と深さ $z$ との関係を求めて Fig. 4 に示す. 入 力電压 $V_{i}=30 \mathrm{~V}, 45 \mathrm{~V}$ のいずれについても， $V$ が $z$ の 4 乗に反比例する関係を示した。

以上の結果により, 式（5）の関係が成立しているこ とが示された.

b ） 新計測法 Fig.5の下図は, 地中のトンネル 機械と地上に設置した受信器の断面図であり，上図は サーチコイルの水平位置に対忘する誘起電圧を示してい

る. 装置については，3.（2）において述べる.

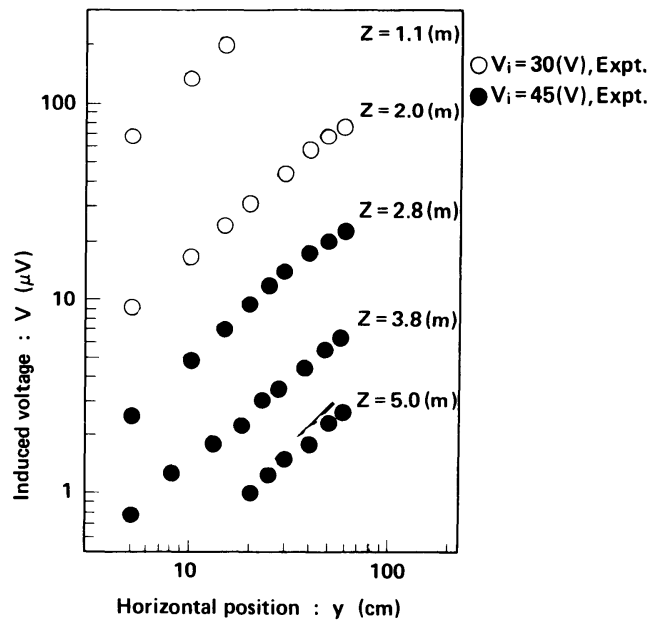

Fig. 3 Relations between induced voltage and horizontal position of search coil $\left(\phi_{x}=\phi_{2}=x=0\right)$.

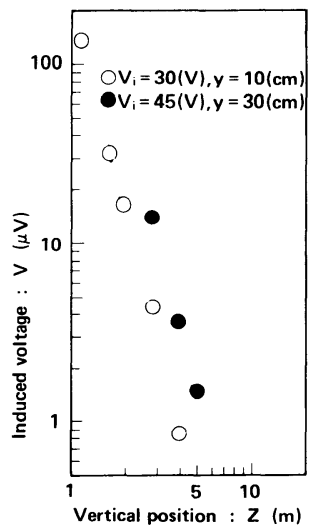

Fig. 4 Relations between induced voltage and vertical position of search coil.
Fig. 5 に示すように同一特性を有する 2 個のサーチコ イルを計画線を中心に, 鎖交面が離隔 $2 L$ をもって正 対し，かつ鉛直になるように設置する。このとき発進坑 からみて左を正， $|Y| \leq|L|$ のとき，式（5）により， 左側のサ一チコイルへの誘起電圧 $V_{L}$, 右側のサーチコ イルへの誘起電圧 $V_{R}$ は,

$$
\begin{aligned}
& V_{L}=\frac{\alpha(L-Y)}{z^{4}\left\{1+(L-Y)^{2} / z^{2}\right\}^{5 / 2}} \cdots \\
& V_{R}=\frac{\alpha(L+Y)}{z^{4}\left\{1+(L+Y)^{2} / z^{2}\right\}^{5 / 2}} \cdots
\end{aligned}
$$

となる。

また，近似式（6）によれば, $V_{L}, V_{R}$ は,

$$
\begin{aligned}
& V_{L}=\alpha\left(L-Y^{\prime}\right) / z^{4} \\
& V_{R}=\alpha\left(L+Y^{\prime}\right) / z^{4}
\end{aligned}
$$

となる。

式（9), 式（10）を，2個のサーチコイルの対称軸 に対するトンネル機械の水平位置の近似值 $Y^{\prime}$ について 解けば,

$$
Y^{\prime}=\left(V_{R}-V_{L}\right) L /\left(V_{R}+V_{L}\right)
$$

を得る。

一方, 式 (7), 式 (8) の 12 次方程式から水平位置 $Y$ を解くことは困難であることから, 次の方法で $Y$ を 解析的に求めた。 $V$ と $y$ との非線形性に起因する水平

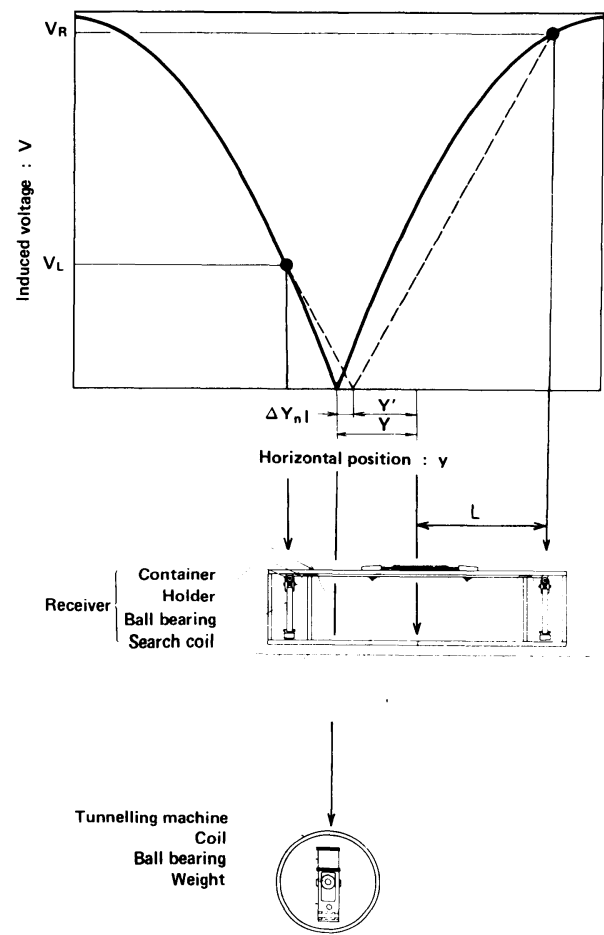

Fig. 5 Method to measure horizontal position of tunnelling machine. 
位置 $Y$ と近似值 $Y^{\prime}$ との差 $\Delta Y_{n l}(Y)$ は, 式 $(7)$, 式 ( 8 ) を式（11）に代入して求めた $Y^{\prime} と Y$ との差をとるこ とにより,

$$
\begin{aligned}
& \Delta Y_{n l}(Y)=Y-Y^{\prime}=Y- \\
& \left(\frac{\frac{(L+Y)}{\left\{1+(L+Y)^{2} / z^{2}\right\}^{5 / 2}}-\frac{(L-Y)}{\left\{1+(L-Y)^{2} / z^{2}\right\}^{5 / 2}}}{\frac{(L+Y)}{\{L-Y)}}\right) L
\end{aligned}
$$

のように，Yの関数として容易に与えることができる. ここで, $Y$ と $Y^{\prime}$ とはほぼ等しいので, $\Delta Y_{n l}(Y) \approx \Delta Y_{n l}$ $\left(Y^{\prime}\right)$ とみなし得る。ゆえに，

$$
\begin{aligned}
& Y=Y^{\prime}+\Delta Y_{n l}(Y) \approx Y^{\prime}+\Delta Y_{n l}\left(Y^{\prime}\right)=2 Y^{\prime}- \\
& \left(\frac{\frac{\left(L+Y^{\prime}\right)}{\left\{1+\left(L+Y^{\prime}\right)^{2} \mid z^{2}\right\}^{5 / 2}}-\frac{\left(L-Y^{\prime}\right)}{\left(L+\left(L-Y^{\prime}\right)^{2} / z^{2}\right\}^{5 / 2}}}{\left\{1+Y^{\prime}\right)}\right) L
\end{aligned}
$$

を得る。ここで， $Y^{\prime}$ は式（11）による.

$V$ と $y$ との非線形性は, $L$ が大, $z$ が小であるほど 大きくなる。ここでは， $L$ は装置化した $30 \mathrm{~cm}, z$ は適 用範囲 1.5 $5 \mathrm{~m}$ の中で比較的小さい值 $2 \mathrm{~m}$ という条件 において, 式 (12) に示した $\Delta Y_{n l}(Y)$ と $Y$ との関係を 実験で確認し，その結果を Fig. 6 に示した。 $\Delta Y_{n l}$ は， たとえば，Fig. 2 における誘起電圧のたるみ量に深く関 係しており，このたるみ量は誘起電圧の絶対值に比べて

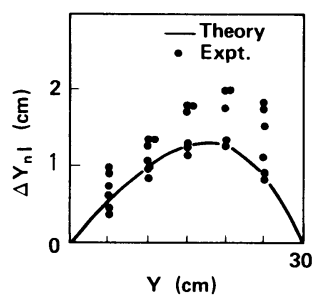

Fig. 6 Relation between difference due to nonlinearity of induced voltage and horizontal position.

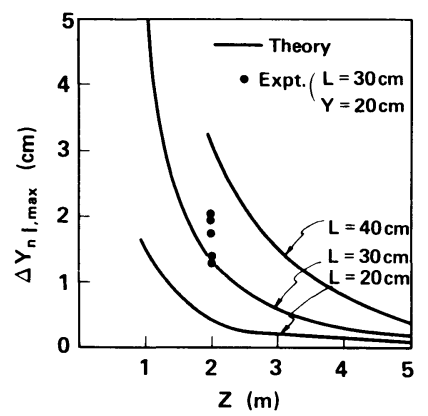

Fig. 7 Relations between maximum difference and vertical position.
小さい. そのため, Fig. 6 のばらつきはFig. 2 に比べて 大きいが，理論值と実験値とはほぼ一致しているとみな せる. $\Delta Y_{n l}(Y)$ は, $Y \approx 0.6 L$ 付近で最大となり $Y=0$ と $Y=L$ で 0 となる.ここで, 最大值 $\Delta Y_{n l, \max }$ を, $L=20$, $30,40 \mathrm{~cm}$ のそれぞれに対して， $z=1 \sim 5 \mathrm{~m}$ の範囲で求 め, Fig.7に示す. たとえば, $L=30 \mathrm{~cm}$ のきき, $z>2.5 \mathrm{~m}$ では, $\Delta Y_{n l, \max }$ は $8 \mathrm{~mm}$ 以下ときわめて小さ くなる.

水平位置を求める式 (13) の方法は, $0 \leq Y \leq L$ の範 用で非線形性による誤差は小さいが，たとえば2. (6) に述べる方法で $z$ を与える必要があるので，迅速性に やや難がある.一方, $z$ を求める必要のない簡易な式(11) の方法は, $z$ が小さいときには計测範囲を絞り， $V$ と $y$ との非線形性による誤差を小さくすれば，より実用的 である.式 (11) の方法を，(2 ），a）に述べた“計測法 2” と区別するために，“計測法 $1 ”$ と呼称し，4.に述べる 推進実験で実用性を確認した。

\section{（3）地中伝搬特性}

土による磁界の減衰を実験により確認した。

実験場の土質は, 深さ $0.6 \mathrm{~m}$ 程度までは黒色の表土, それ以下 $3.3 \mathrm{~m}$ 程度までは, 含水比 $50 \sim 100 \%$, 間隙 比 $2.1 \sim 2.8$, 湿潤密度 $1.3 \sim 1.5 \mathrm{~g} / \mathrm{cm}^{3}$ の茶褐色で均一 なローム層である. 実験は, Fig. 1 において, $x=y=0$, $\phi_{x}=\pi / 2$ の条件で行った.この条件は, サーチコイル の角度，位置設定精度が悪くとも， $V$ と $z$ との関係を 精度よく計測できることが特徴である.

このとき, 理論値は, 式 $(1) \sim(4)$ から,

$V=\pi f \mu N_{1} N_{2} a^{2} S I_{i} / z^{3}=2 \alpha / 3 / z^{3}$

となる. 式 (14) により得られた理論値, ならびに種々 の条件における実験値はFig. 8 のようになる.コイル単

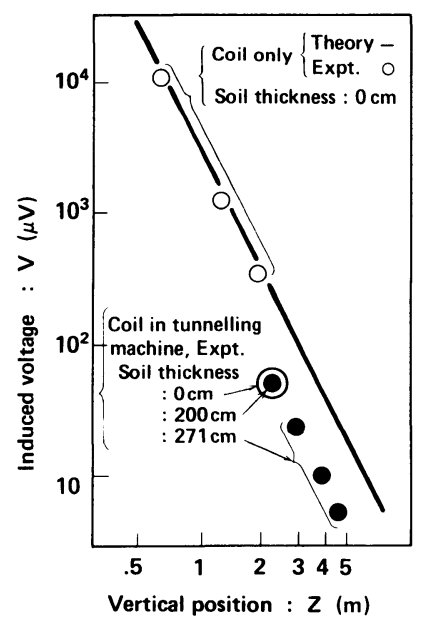

Fig. 8 Relations between induced voltage and vertical position of $\operatorname{search} \operatorname{coil}\left(\phi_{x}=\pi / 2, x=y=0\right)$. 
体で，空中という条件では，白丸が示すようにVが理 論值どおり $z$ の 3 乗に反比例した。同様に，コイルが トンネル機械内に設けられ，土中にあるという条件でも， 黒丸が示すように, $V$ が $z$ の 3 乗に反比例した．また， コイルがトンネル機械内に設けられた状態で，土の厚さ が $0 \mathrm{~cm}, 200 \mathrm{~cm}$ のいずれの場合も, 誘起電圧は等しかっ た.これらの結果から，周波数 $220 \mathrm{~Hz}$ という低周波の 場合，口ームでの減衰は空中での減衰と同様であると結 論される.

また，本装置では， $z \approx 2 \mathrm{~m}$ でのデータが示すごとく， コイル単体の場合に対して，トンネル機械内に設けられ た場合は約 3 分の 1 に減衰した。ここで, コイルを包む ケース（厚さ $3 \mathrm{~mm}$ )，ならびにコイルが収容されるト ンネル機械のヘッド（外径 $340 \mathrm{~mm}$ ，厚さ $12 \mathrm{~mm}$ ) の材 質には，磁界の減衰を少なくするために，非磁性体で低 導電率のステンレス鋼を用いている。なお,ケースにベー クライトを用いた場合は, 減衰はヘッドのみにより生じ, 2 分の 1 であった。

\section{(4) 最大計測深さ}

最大計測深さ $z_{m}$ は, 選択レベル計の最小検出可能電 圧 $V_{\min }$ ，あるいは騒音レベル $V_{n}$ によって制限される. コイル間隔 $L=30 \mathrm{~cm}$, 計測範囲 $L^{\prime}=10 \mathrm{~cm}$ とすれば, 誘起電圧は $Y=L^{\prime}$ のとき最小となる. さらに, コイル 搭載部での減衰率 $\beta_{1}=1 / 2$, フェライト磁芯による増幅 率 $\beta_{2}=4.1$ を式（6）に考え合わせ， $V_{\min }$ は,

$V_{\min }=\beta_{1} \beta_{2} \alpha\left(L-L^{\prime}\right) / z_{m}^{4}$

となる.

式（15）から入力電圧 $V_{i}=50 \mathrm{~V}$ (定格) で， $z_{m}=5 \mathrm{~m}$ を可能とする $V_{\min }$ として, $0.6 \mu \mathrm{V}$ を得る. $0.6 \mu \mathrm{V}$ は, 高感度の選択レベル計を用いれば計測可能な值であると ともに, 騒音レベルが $0.1 \mu \mathrm{V}$ 程度であったことから, 本計測方法は目標の $5 \mathrm{~m}$ まで適用できると結論される.

\section{（5）自動車による磁界騒音}

自動車のエンジン部は, 幅広い周波数帯域をもつ電磁 界を放出し，本計測に用いる $220 \mathrm{~Hz}$ も含まれている. そこで, 2 車線, 車線幅員 $3.75 \mathrm{~m}$ の国道の傍らにて, 路肩から $1.4 \mathrm{~m}$ の位置に, サーチコイルの鎖交面を鉛 直かつ道路に平行に設置して, 騒音レベルを計測し, 水 平位置計測への影響を確認した。

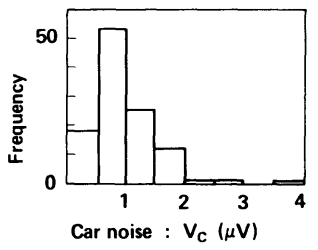

Fig. 9 Amount of scatter in car noise.
その結果，Fig.9に示すように，129台のうち $85 \%$ が $0.5 \mu \mathrm{V}$ 以上の騒音レベルであり，Fig. 3 に示した誘 起電圧に比較すると，土かぶりが大きい場合には，誘起 電圧の計測に対して影響が大きい。ゆえに，誘起電圧計 測は, 自動車が受信器の直前を通っていないときに行う 必要がある。 また，2（２），a）に述べた計測法 2 の場 合でも，このノイズは誘起電圧の最小值の探索を困難に する.

しかしながら，3．に述べる施工実験の結果では，“計 測法 1”の場合, 電圧の実計測時間は, 片側のサーチコ イルに対して約 10 秒であり，自動車の通行が途切れた ときに計測することが十分可能である. 一方, 計測法 2 の実計測時間は約 40 秒であり, “計測法 1 ”に比べると 適用性は劣る。

\section{(6) 深さ計測}

2. ( 2 ), b) の条件と同じく, $\phi_{x}=\phi_{z}=x=0$ における 一対のコイルへの誘起電圧 $V_{L}$ と $V_{R}$ を加えると，すな わち, 式 (9) と式 (10) の辺々を加算すると, 未知数 $Y$ が消去され, 深さ $z$ を一義的に与える式,

$$
z=\left\{2 \alpha L /\left(V_{L}+V_{R}\right)\right\}^{1 / 4}
$$

を得る。

また, 2. (3)の条件と同じく, $x=y=0, \phi_{x}=\pi / 2$ とすれば, サーチコイルの水平位置, 角度によって誘起 電圧が大きく変化しないうえに，たとえば， $L=30 \mathrm{~cm}$, $z=2 \sim 5 \mathrm{~m}$ のとき, 誘起電圧は2. (2),b) の条件にお ける $\left(V_{L}+V_{R}\right)$ に対して 2.2 2.6 倍となるのでノイズ の影響を受けにくくなる，などの理由から深さをより精 度よく知ることができる．2. ( 3 ) の条件のとき，深さ $z$ は式 (14) 加ら

$$
z=(2 \alpha / 3 / V)^{1 / 3}
$$

となる。

式（16）あるいは式（17）から，任意の $z$ において, $\alpha$ を実験的にあらかじめ較正しておけば，誘起電圧から 容易に深さ $z$ を求めることもできる.

\section{3. トンネル施工実験}

\section{（1）トンネル工法の概要}

本水平位置計測装置を適用したトンネル工法のシステ ムを Fig. 10 に示す。このシステムは，推進方向を修正 しつつトンネルを圧入無排土式に形成するトンネル機 械8)，トンネル機械に後続する埋設用鋼管，鋼管を押す 押管装置, トンネル機械と押管装置に設けられた油圧 ジャッキを作動させる高圧油を供給する動力装置, トン ネル機械の姿勢角などを表示しオペレーターがそれに基 づいて機械を操作することができる制御盤，そして本論 文に述べている水平位置計測装置から構成されている.

トンネル機械は次のごとく推進される.はじめに,ヘッ 


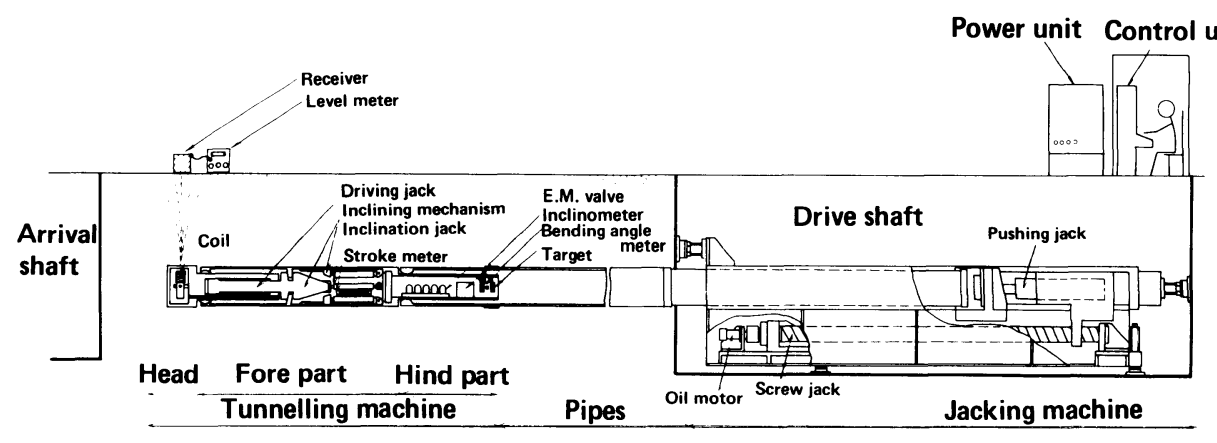

Fig. 10 Pipe jacking method.

ドを方向修正する方へ傾けた後, 前部の推進ジャッキを 伸ばしてヘッドを土中に圧入推進させる. 次に, 推進 ジャッキを縮めると同時に，押管装置の押管ジャッキを 伸ばして, トンネル機械の前部と後部，ならびに鋼管を 同時に推進させる.この過程を繰り返すことにより，鋼 管は逐次埋設される.

\section{（2）水平位置計測装置}

2. ( 3 ) に述べた, “計測法 1”において発信用のコイ ルと一対のサーチコイルに要求される幾何学的条件を調 整することなく満足できるように, Fig. 5 下図に示した 装置を製作した.

発信用のコイルは, 連結された重りの重力作用により 軸心が鉛直となるように, 回転と傾斜に対応できる 2 軸 のボールベアリングを介して, トンネル機械のヘッドに 取り付けられている. また, 1 対のサーチコイルは, そ の鎖交面が正対し, かつサーチコイル自身の重力作用に より鉛直となるようにボールベアリングを介して受信器 のホルダーに取り付けられている. したがって, 埋設管 の押込量から知られる推進地点において, サーチコイル の鎖交面が推進計画線とほぼ平行になるように受信器を 単に置くのみで, 計測の準備は終了する.

また, サーチコイル間隔 $2 L$ は次のように決めた. それまでの軌跡を延長することにより， $Y<0.1 \mathrm{~m}$ 程度 の精度で受信器を設置することができる.このとき,サー チコイルと発信コイルとの水平距離 $y$ は, 一方が $(L-0.1) \mathrm{m}$, 他方が $(L+0.1) \mathrm{m}$ となる. そして, 本 工法の適用深さが $1.5 \sim 5 \mathrm{~m}$ であることから, $y=(L+0.1) \mathrm{m}, z=1.5 \mathrm{~m}$ の場合に, $y / z$ は最大值とな る. 一方, Fig. 2 から, 誘起電圧 $V$ と $y$ との線形性が 高いのは, $y / z \leq 0.25$ の範囲である. ゆえに, $(L+0.1)$ $/ 1.5 \leq 0.25$ の条件式が得られ， $L \leq 0.3 \mathrm{~m}$ となる. ここ で，Lが大きいほよ゙, 誘起電圧が大きくなり, ノイズ による影響も小さくなるので, $L$ 小 $0.3 \mathrm{~m}$ とした.

発信用のコイルは, フェライト棒 $(\phi 10 \mathrm{~mm} \times 70 \mathrm{~mm})$ を磁芯とした巻数 1500 回のチョークコイル（コイル内
径 $14 \mathrm{~mm}$, 外径 $\left.40 \mathrm{~mm}, L_{1}=97 \mathrm{mH}, R_{1}=5.4 \Omega\right)$ であり, サーチコイルは, 有効断面積 $32 \mathrm{~cm}^{2}$, 巻数 2000 回の空 心ループコイル $\left(L_{2}=256 \mathrm{mH}, R_{2}=205 \Omega\right)$ である.

なお，磁界への影響を少なくするため，発信用のコイ ルを搭載しているへッド同様に, 受信器についても, サー チコイルを支持する部材にはステンレス鋼を用いるとと もに，ケース全体はデルリン樹脂を用いた。

\section{(3) 計 測 結 果}

前節に述べた実験装置を用い, 深さ約 $2.5 \mathrm{~m}$ で, 曲 率半径 $200 \mathrm{~m}$ の曲線を含む距離 $90 \mathrm{~m}$ のトンネル施工実 験を行った.この実験において, 2. に述べた計測法 1 , ならびに計測法 2 によって, トンネル機械が $2.5 \mathrm{~m}$ 進 むごとに推進計画線からの位置を計测し, 方向修正を実 施した. そして, 水平位置計測の精度を確認するため, 推進終了後, 埋設部全体を開削し, 埋設管の水平位置を 光学測量した.

実験場の土質は, 深さ $0.2 \mathrm{~m}$ 程度までは暗褐色の表 土, それ以下 $1.8 \mathrm{~m}$ 程度までは, 含水比 $80 \sim 120 \%$, 間 隙比 $2.3 \sim 3.9$, 湿潤密度 $1.3 \sim 1.5 \mathrm{~g} / \mathrm{cm}^{3}$ の茶褐色の ローム, それ以下 $2.5 \mathrm{~m}$ 程度までは, 含水比 $55 \sim 60 \%$, 間隙比 $1.5 \sim 1.6$, 湿潤密度 $1.64 \sim 1.67 \mathrm{~g} / \mathrm{cm}^{3}$ の灰色粘 土である。

計測結果をFig. 11 に示す. 光学測量值を実線で, 計 測法 1 による值を○印で, 計測法 2 による值を口印で表 わしている. 光学测量值, すなわちトンネル機械に後続 する鋼管の位置は, 完全には本水平位置計測法による值, すなわちトンネル機械のヘッドの通った位置と同一のも のではないが, 本水平位置計測法による值は光学測量值 によく一致した. ここで, 光学測量值との差の度数分布 をとり, Fig. 12 に示す. 計測法 1 は, 計測法 2 よりば らつきが少ない結果となり, 標準偏差 $\sigma$ は $1.36 \mathrm{~cm}$ で あった. また, 差の最大值は両計測法ともに約 $4 \mathrm{~cm}$ で

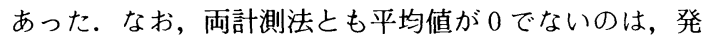
信側, もしくは受信側のコイルの鉛直度の誤差に起因す ると考えられる.なお，ここでは約 $1 \mathrm{~m}$ の粘土層を含 


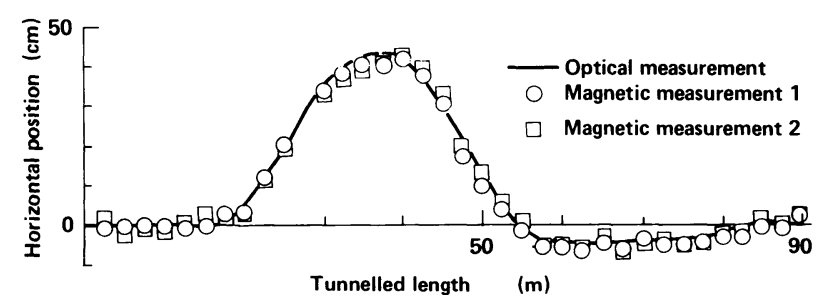

Fig. 11 Measured horizontal positions of tunnelling machine.
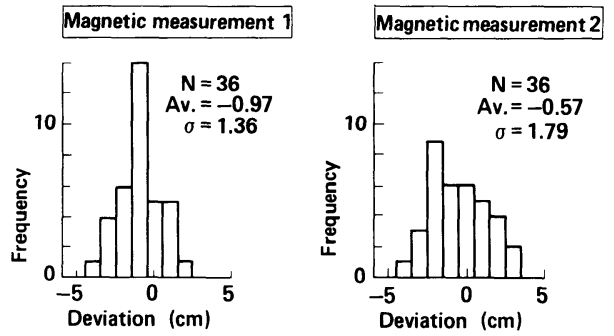

Fig. 12 Amount of scatter in measured values.

んでいるが，ほとんどがロームの場合 ${ }^{5)}$, 砂の場合9)に ついても磁界による計測法の有効性は確認されている.

また, 計測時間は, 計測法 1 の場合, サーチコイルが 静止するまで 10 ２0 秒，両オサーチコイルへの誘起電 圧を読み取る時間 10 秒 $\times 2$ 回, 合計 30 - 40 秒であった. 一方, 計測法 2 の場合, サーチコイルの鉛直度の調整に 約 50 秒，走查に約 40 秒，合計約 90 秒であった。この 結果, 計測法 1 が計測法 2 より迅速に計測できることが 示された.

\section{4. まと め}

従来, トンネル機械の絶対水平位置計測は, トンネル 機械の長距離・曲線施工を妨げていた大きな問題の 1 つ であった。これに対して，本論文では，土による減衰や 近傍金属体による影響が少ない低周波の磁界を媒介之 し, 安価で感度の高いコイルを磁界測定センサとする方 法において，サーチコイルへの誘起電圧の空間分布特性 と振り子構造における重力作用を応用することにより， サーチコイルの位置・角度の調整や走査が不要で, 高速 かつ高精度な計測法を提案した.さらにトンネル機械に 適用して, トンネル施工実験を行った結果を示した。 得 られた結果を要約すると以下のとおりである.

（1） 発信コイルの中心軸, ならびにサーチコイルの 鎖交面が鉛直，かつ深さが一定のとき，サーチコイルの 誘起電圧は, サーチコイルと発信コイルとの水平距離に ほぼ比例する。

（2）間隔 $2 L$ なる一対のサーチコイルにおいて, 左側の誘起電圧を $V_{L}$, 右側の誘起電圧を $V_{R}$ とすれば,
サーチコイルの対称軸からの発信コイルの水平位置 $Y$ は次式で与えられる.

$$
Y=\left(V_{R}-V_{L}\right) L /\left(V_{R}+V_{L}\right)
$$

（3）本実験で選定した周波数 $220 \mathrm{~Hz}$ の場合, ロー ムでの減衰は空中での減衰と同等であった，また，発信 コイルを収容するトンネル機械による減衰は $1 / 2 \sim 1 / 3$ であった。

（4）自動車による磁界騒音レベルは，本位置計測に 対して影響を及ぼすが，本位置計測法の実計測時間が約 10 秒であることから実用上は間題ない.

（5）一対のサーチコイルを, 鎖交面が正対する位置 にて，ステンレス製のホルダーにボールベアリングを介 して取り付け，これらをデルリン樹脂製のケースに収め ることにより, サーチコイルに要求される幾何学的条件 を, 調整することなく満たす, 操作性のよい受信器を実 現した。

（6）深さ約 $2.5 \mathrm{~m}$ のトンネル施工実験において, トンネル施工後の開削による光学測量値之, 本水平位置 計測値との差の最大值は約 $4 \mathrm{~cm}$, 差のばらつきの標準 偏差は $1.36 \mathrm{~cm}$ であった。また, 計測時間は, サーチ コイルが静止するまで 10 20 秒, 両サーチコイルの誘 起電圧を読み取る時間が 10 秒 $\times 2$ 回, 合計 $30 \sim 40$ 秒で あった。

（7）簡易かつ高精度な本水平位置計測装置の開発に より, 曲率半径 $200 \mathrm{~m}$ の曲線を含む, 距離 $90 \mathrm{~m}$ の長距 離・曲線施工を実現できた。

今後は, 深さ, 発信コイルへの入力電圧, 選択増幅器 の計測精度，などに起因する計測誤差，ならびに近傍金 属体による計測誤差について研究を進める.

謝辞：本研究をまとめるにあたり, 適切なるご教 示亡助言を頂いた茨城電気通信研究所 小島伸哉部長, 内 田直也統括役, 山岸康利室長, ならびに森光武則調査役 に感謝する.

また, 本研究の基礎を築かれた有岡良祐調査員, 森 純男社員に感謝する.

$$
\text { 参考 文 献 }
$$

1）開田生一：小口径推進工法, 土木施工, Vol. 22, No. 6, 
pp. $27 \sim 36,1981$.

2）本岡誠一・奥島基良：インパルス音源による地下埋設物 の探査実験, 音学誌, Vol. 33, No.6, pp. 311 318, 1977.

3）荒井郁男・鈴木 務：地中レーダシステム, 電子通信学 会論文誌, Vol. J66-B, No.6, pp.713 720, 1983.

4）金子隆司・山崎 智 - 長谷川将 - 楠 迪彦 - 只津良輔： 心線給電法による地下埋設物探知, 信学技報, CS 80-82, 1980, 08 .

5）梅津孝雄・野村由司彦・保科宏・塩見博司：小口径卜 ンネルマシンの水平位置計测法, 電子通信学会論文誌, Vol. J67-B, No. 6, pp. 690 691, 1984.

6）野村由司彦：トンネル機械の方位角・水平位置計测法,
電子通信学会論文誌, Vol. J67-B, No. 6, pp. 615 621, 1984.

7）副島輝積 - 堀内和男: 電磁気学, 電子通信学会編, コ口 ナ社版, pp. 212 216, 1964.

8）野村由司彦・保科宏・塩見博司・梅津孝雄：方向制御 可能なトンネル機械の設計と特性, 土木学会論文集, No. 352, pp. 99 107, 1984.

9) Nomura, Y., Hoshina, H., Shiomi, H. and Umezu, T. : Pipe jacking method for long curve construction, Jour. of Construction Division (ASCE), Vol.111, No. CO2, 1985.

(1984.6.30 - 受付) 